\title{
The Study of Univocal and Polisemantic Words from "The Albanian Nowdays Language Dictionary" 1980 to "The Albanian Language Dictionary" 2006
}

\author{
Jonida Cungu \\ Tirana University \\ E-mail: jonida_cungu@yahoo.com
}

Doi:10.5901/ajis.2013.v2n4p311

\begin{abstract}
:
The lexical structure of the word is open and changeable, which is always associated by the different of the time. These changes don't include only special word, but the whole fond of Albanian words reflected to the dictionary. So, for this study it has been necessary the support of the two biggest work of Albanian language: "The Albanian language dictionary of nowadays" 1980 and "The Albanian language dictionary" 2006. It's evident that language is enriched by new entry of lexical units, but the linguistic enrichment it is not seen only at the number of lexical units, which enter or get out the uses. We are trying to argue that the linguistic development is preceded from the relation between the words, which produces changes at many linguistic phenomena as mono semantism and polisemantism. The words give special types, so they create relationships between speaking and writing speech, create relationships between active and passive lexis, and at the semantic structure of the words, which is reflected at the changes of semantic versions of the words. So, they bring a qualify development of the Albanian semantic structure. There are estimated and brought out from the two dictionaries all the univocal words, ambiguity words and polisemantic words, the changes of this kind words during these years and the percent that mark them at the fond of the Albanian words. This numbering it makes us possible to give dates for the effects that give the increase of polisemantic and monosemantic words to Albanian language. The study of the changes at lexical structure of Albanian words gives help at the improvement of data for lexicological and semantic.
\end{abstract}

Key words: univocal, ambiguous, polisemantic words, increase, monoseamantism, dictionary.

\section{Introduction}

The study of lexicology and semantic have always had interest because of their discussed problematic that they include. The lexica, being the first direction of linguistic changes, brings great changes at linguistic system situation. So, the study of lexicology posses an important step at the improvement of linguistic system's data.

The language, all over its existence, shows novelty and achievement, which happens so slowly without being understanding from the speakers. The directly influence of factors which influence at the language, especially shows at lexica development, which reflects the changes in an opened and immediately manner. The lexical structure of the word is an opened and moving structure, which is always associated with changes resulting from the times. These changes didn't connect only special words, but the whole fond of Albanian lexis.

The object of this study is to show the movement of lexical structure of the words, the effects that brings the mobility of semantic contents and the existence of univocal and polisemantic words at Albanian language.

The words present a new structure at different times, depending on the movement that it has incurred. The movement could connect the semantic content of the words, which influences to the extension or to the restriction of the structure. It is obviously from the examination of the material, that the lexical fond of Albanian words is growing up as quantity with many new lexical units, by quick rhythm. But these lexical units have not to be seen only in quantitative aspect, but to the qualitative aspect too. The word is born, takes shape, changes and can not be used anymore. The most important periods of its life is to take shape and to develop. 
If the words can generate new meanings, they can be productive for the language. On the other hand, if they don't generate new meanings, if they have a strict character, they can be a lot for the language. They could to have the ability to take shades of meanings, to derive new meanings and to be the source for the increase of the words to Albanian language. So, to be productively at language, they have to posses the ability of the development. But, what happens at Albanian language with the structure of lexical units?

\subsection{Method:}

To accomplish this study are used the two great works of Albanian language: "The Albanian nowadays language dictionary" 1980 and "The Albanian language dictionary" 2006. They are the mirror of linguistic reality, which is in an uninterrupted and unstoppable development. The source of their semantic contents is from the active field of language, so they are a valuable searching material for the object of the study. It is made a regular and carefully account of eliminated meanings of the polisemantic words and the new semantic versions of the words. The two dictionaries have served to compare the value of univocal, ambiguity and polisemantic words from one dictionary to other. The comparison is done carefully, so the level of mistakes is too low. This method help us to give right conclusions about the value of monosemantism and polisemantism to Albanian language.

\section{The structure of lexical units at Albanian language}

\subsection{The lexical experience}

The Albanian lexicography has a long time life. We found the beginning of this work since 1600 , the same period when was the great Albanian social movement. Even though the Albanian language is standardized late, in 1972, the strikes for a national and standard language are raised since the movement of Albanian National Renaissance. The intellectuals of that time have done e great effort to resolve the problematic of the Albanian society as: the forming of Albanian state and the Albanian language. That was the period when they were firmly rooted of Albanian national language. But at this condition was impossible to be published an explanatory dictionary. Only some bilingual dictionaries were possible to be published, but not from the Albanian authors. They were published from foreign authors. Even though they couldn't be at the role of a sure explanatory dictionary.

The first Albanian explanatory dictionary will be the work of K. Kristoforidhi, (1904). It contains a great work of him for 20 years and a rich material from the lexica and phraseology. He gives not only the words that had collected all over his country, but he gives the explanation for each word. This is a great contribute for that time, meanwhile didn't exist the Albanian state and all over the country were spread the Turkish language. So, the first positive thing from Kristoforidhi was the attempt to collect and to present a dictionary for his country.

A great work at lexicology field was done from A. Xhuvani, who studied not only the words of lexis, but he did a scientific glance at Albanian language. His thought about the purity of language and the tendency for avoiding the uses of foreign words, is even now an actual and real problem for our language. At one of his study, he said: "It is necessary to know that language it is not unimportant. It is not a privilege for only some people that has the obliquity to study it, but it is the owner, the property of all the people, the true sign of nations, the most precious thing for everybody. So, we have a great obligation, to take care about it's purity and it's flourishing" (1958, pg. 70).

The study at lexical field were enlivened after 1970. The study that were teeming most are: the study of words which are used at terminology field, phraseology and word-formation. Than a great number of studies were about the polisemy, the content structure of the words, homonymy etc. The situation is represented different these years and it will changed positively after 1972, the year of standardizing the Albanian language. 


\subsection{The changes the structure of lexical units at Albanian language}

The Albanian language has univocal words, ambiguous words and polisemantic words. To express an word with only one meaning, it means that one notion responded one reality. When a word has many meanings, they serve to note an only notion at words with two or more meanings. If we are going to compare the lexical fond at two Albanian dictionaries, we will see that the quantities' value of them has done sharp changes. According to reports by Jani Thomai (1989/2009) the Albanian language dictionary of 1980 has over $80 \%$ of the words as ambiguous or polisemantic units. Quantitative and polisemantic words are thought to be included, while $20 \%$ of them included monosemantic words. Today the present of these words at the dictionary shows other values. The totality of polisemantic words notes a reduction with $5 \%$ of value at albanian dictionary of 2006, numbering about $75 \%$ of the lexical unit with two or more meanings. If we are talking about numbers, over 570 lexical units are joined with the group of monosemantic words. This means that consequently we have a growth of monosemantic words. The number of polisemantic words is higher at natyral languages than artificial languages. Albanian language is a natural language, so it has the possibility to owner many multi meanings words. I believe that this happens because of the regulars of linguistic system, which led the words to derive different meanings. When a word pass from a part of speech to another, it can generate new meanings. The contest is an important factor for derivation of the meanings. The contest is so responsible for the new semantic versions of a word, that is impossible to understand the right meanings of the words.

This issue will be argue by the examples given below. There are so many examples of lexical units which change their status from mono semantic to poli semantic, but we will mention only some of them.

The unit -manuscript- comes out with two semantic version at the Albanian dictionary of 1980: 1. text written by hand or type-written. 2 document or work written by hand at early time before typography is used. Today this word has maintained only first meaning, so it is become at mono semantic words. The same thing happens at the unit -suckling piglet- which is become to mono semantic because there aren't anymore the meanings: 2. chubby child, very fat. 3. oval pebble, marble; -to identify- these meanings absent 2. can ascertain someone by the traces that it has done. 3. discover and determinate the distinctive features of a plants or an animal etc.; -camp- these meanings absent: 2. a place encircle by guardians where were kept the prisoners and the prisoners of the war. 3. a political and social group which protect the same interests; barracks- absent only the second meaning 2. large ramshackle house or building; -co-operative- these meanings are absent 2. a kind of socialist and collective agricultural farm. 3. shop or place where could sell the goods of a co-operative; - naiveties- these meanings are absent 2. a big trust at everything that we hear. 3. naivety words or ideas; -indivisible- these meanings are absent 2. something that couldn't take separated from the whole. 3 . When something or someone stays always with something else; -tenant lodger- these meanings are absent 2. Caravan - driver. 3. Horse hirer; -balance- the absent meaning is. 2. Way or manner to appreciate or to judge someone or something; -whale- the absent meaning is 2. (Colloquial) a kind of lash, which is made from the teeth of this animal, but it's impossible to break, that it used as a fortress for shirts; -to confront- the absent meaning is 3 . (Regional) to join two objects, to face up to face two things; -counter- the absent meaning is 3 . The table where works the joiner; -band- these meanings are absent 3 . (sport) a belt from cloth which is used for the volleyball net... 5. (Nautical) a high part of the ship or a boat; -barricadethese meanings are absent 2. (Figurative) a place where people fight or skirmish. 3. (sport) barriers, wall that raise the sportsman by hands or body to defense their goal; - bastard- the absent meaning is 4. (Derogative) a child born out of wedlock; -tail- (figurative, derogative) someone who follows you blindly; -bee- the absent meaning is 4. (Adjective) someone who is so lively; -bronze- the absent meaning is 2. (figurative, derogative) something that doesn't have a great value or doesn't appreciate as well; -distinction- the absent meaning is 3. The unequal differentiation of people and things, preferring them without any value; -Darwinism- the absent meaning is 2. a subject which gives the essential knowledge of this science at school; -dean- the absent meaning is 4 (history) a commander of ten soldiers at roman army; -freshness- the absent meaning is 3. (Figurative) something original and alive that give us pleasure, presenting in a nice way or manner; -broom- 
the absent meaning is 3 . a flock of reeds with a tail, which is used usually from the blacksmith to collect the fire and to sprinkle by water; - to invite- the absent meaning is 3 . to bring someone to court; -plain- the absent meaning is 9 . a place on the table where we put the cards; -throat- the absent meaning is 6.(colloquial) one gulp of water; - face- the absent meaning is 5.(specific use) figure; -to quack- the absent meaning is 2.(figurative, colloquial) speak too much, to blabber by hoarse voice; -to galvanize- the absent meaning is 2.(figurative) push someone for an action towards someone else or something; -ladle- the absent meaning is 2.(figurative) someone who quarrel over nothing; -newspaper- the absent meaning is 2. (colloquial) the editorial office which publish that journal, the office and the building where the editorial office is; -mouth- the absent meaning is 8.(colloquial) a dialect, an idiom of an region; - glass- the absent meanings are 3.(colloquial) an electric lamp. 4. A person who drinks alcoholic drinks too much; -to hook- the absent meanings are 2. To bled a part of the body stung by the viper and 3. To prick by needle the place which was stung by the snake; -belching- the absent meaning is 3 . (Figurative) a bad man, filthy person; -iron- the absent meaning are 2. (chemistry) the salt of this metal as a substance and 5. (Nautical) hook or anchor and 6. (sport) oval hook made from iron, fastened over two columns which is used to make gyms exercises, etc. ${ }^{1}$

If we are going to count the number of eliminated meanings, we will see that they are in a great number, about one thousand (1000) meanings. That means that the content structure of the words had incurred big changes, because of many factors which influence permanently to the language. Every word is associated by stylistic notes as: figurativ, colloquial, nautical, regional, botany etc. The great parts of the words have the notes as -figurativ-. This means that the words which owner the figurativ meaning have the possibility to generate other meanings or to come out as new lexical units. The stylistic note figurativ is the first step of a word to derivy new meanings. When the words develop that stylistic note, it means that the word has derivied new semantic versions, which it will be later a possibility for this meaning to come out as a new lexical units. But there is a great part of words which have terminologyc notes. These words are used for a special field, but the have a big influence to the content structure of the words, because of their strict character.

These examples can be explained not only with linguistics development, but even with the changes of social life. Many semantic meanings are not useful today, because of the fact that they don't have any field to be active. So they are become passive and the possibility to be unuseful is really concrete. The more so, changes that has incured our country at political and social aspects, condition a big number of meanings to get out from the practical speech. At the same time, language has the instruments to improve its losts. The growth of univocal words at this numbers, may be not disturbing for the language, because it runs the language to a great enrichment of the lexical fond. But the most disturbing thing is the lexical content of univocal words. If the content structure is warmish, the possibility to generate new other meanings will be so little. This point can be explained with the new entries at albanian language. The development of technology which has been unknown before for the albanian society, has made possible to enter a great number of new words from different fields, but especially from technology. This means that they are words which can be used only for one special field. But this word has a punctual nature. Because of their solid structure and warmish lexical content that they posses, they have little possibility to generate semantic meanings. (Haxhillazi, P. 1972) For example: discette, computer, cocaine, stress, structuralist, subsidise, subversive, frame, ferry, tramway etc.

The eliminated semantic meanings which are separated from the structure of the word, often are joined with each-other at one only meaning by semantic criterion (some examples are given above). The connection of this meaning, the affinity between them, does that the semantic knot to be responsible to join and relate special meanings at one. If this presantion to the dictionary is right or not, it will need a semantic analysis of lexical units which appear this phenomenon. But the most important thing is the consequence. The

1 Notes: The given examples are referenced the presantion of the words at "The Albanian nowdays language dictionary" 1980 
phenomenon of monosemantism is noted progress, eventhough it is in low value. The question is raised: is it threatened the albanian language from the monosemantism?

\section{The effect and consequences of monosemantism}

The monosemantism is a medal by two sides. Its positivity consists at the simple fact, one notion responses one reality. This thing doesn't answered the linguistic economism. Eventhough the linguistic's practice decides the way how language can answered this phenomenon. On the other hand, monosemantism helps the language to enrich the lexical fond. The words ought to have the development ability, being useful for language. Only on this way the words can take new shades of meaning, to derivate meanings and to be a source for the increase of new meanings and new words at albanian language. The loan-words from the other languages, which belong especially the teminologic fields, are included at the lexical fond, because the language it's not able to find the albanian answered. These words haven't the possibility of semantic development. Because of that, they can't be a useful source for albanian language, which is well-dispossed to enrich from the meaning's development than from the word-formation, by the traditional grammatic.

The grouth of univocal units at albanian language has let traces at other kind of units, at ambiguous and polisemantic units, because the narrowing lexical contents, it has taken the places of other units. Every narrowing or extension contents influence directly at a whole group of words, because the lexical units don't exist alone, but they have relationships between them. We can saw these relations in one lexical voice. The elimination and the increase of semantic versions happens at the same time for all the units of lexical center. For example: the verb -to open- has 20 meanings at albanian dictionary of 2006, (pg, 373). As the result of the elimination and increase of the meanings, the same word has 8 meanings at the albanian dictionary of 2006, (pg.14). The same thing happens with the passive of the word, - to be opened- which had 16 meanings and now it has 3 meanings; the noun -opening- from 3 meanings it has to 2 meanings; the adjective -openedfrom 23 meanings it has 5 meanings. This shows the fact that words don't make a separate life, but they keep relations between them, which give movement not only at one point of it. The same thing happens to the other words of one lexical voice as: to throw, to jump, to soil, to be soiled, soiled, to salt, to be salted, to wind up, wound up, to receive, receiver etc.

Some of this kind of changes are explained with the condensation of the explanation of the words, or of the new synthesis meanings and the contamination at one meaning. ${ }^{2}$ Eventhough, its necessary to say that a great number of the words at their presentation at the dictionary have the restriction of meanings. But it needs to emphasizes that aren't the dictionaries the object of this study, which are always in the center of many critics, because they shows the linguistic reality. The dictionaries serves in this study as an object, as helping to see the changes of univocal, ambiguous and polisemantic words.

It is necessary to speak too, for the semantic versions and for the new shades of meanings which are increased at lexical units. The fond of albanian words has noted an increase with over 200 semantic units during these 30 years. They have influenced positively at the extension of the contents structures of the words, doing the possibility to pass from univocal units to ambiguous and polisemantic words. These are some of the examples:

The word -bull- has these semantic versions at the dictionary of 1980: 1. two or three years old calf. 2. the most thickly sleeper at a house. 3. stocky young man. This word increased with a new meaning at the dictionary of 2006, which is - one of the 12 signs of zodiac-. The same thing happens at the word: -to attractto allure, to make somebody come after me. Now it has a new meaning -to put out the fire-; -to button- is added the meaning 2. to put a lid on a work; - to congratulate- is added the meaning, 3 . to declare someone as able to be saint; -to harness- is added the meaning, 2. to pick a quarrel with someone; -cramp- is added the meaning, 2. to stop immediately a work; -packet- is added the meaning, 3. a packet of laws that answered 
for a question; - priest- are added the meanings, 2. a thick wood which is used to hold the roof. 3. an wood which is used as hanger for clothes; -to reappear- is added the meaning, 2. repeat; -fence- is added the meaning, 2. baking-pan; -pile- are added the meanings, 2. cap. 3. placed one over the other; -stuff- is added the meaning, 2. content, quality content; -stomach- is added the meaning, 2. belly; - archer- is added the meaning one of the 12 signs of zodiac; childhood- is added the meaning 2. (colloquial) a spoiled behaviour of children; -tribe- is added the meaning 2. a group of people with same costumes and language; -to fling- is added the meaning 2. (figurativ) to discard someone from home; -to intrigue- is added the meaning 2. (bookish) to belive, to plot, to attract; -to feed- is added the meaning to extend the hairs with artificial parts; company- is added the meaning 2. society, enterprise, commercial firm; -worm- is added the meaning 3. (figurativ) to be worried about, to affect with disease; -rig-dove- is added the meaning 2. (figurativ) a beautiful girl; -sloppy- is added the meaning 3. (figurativ) a person without dignity; -marathon- is added the meaning 2. something that is taking such a long time; - morning- is added the meaning 2. morning prayer; - to spread- is added the meaning 3. to represent, to propound; - cramp- is added the meaning 2. (figurativ) an immediat interruption of an action, which has negative consequences; - to harden- is added the meaning 2. (figurativ) to turn into a stone, etc. ${ }^{3}$

\subsection{The effect of extension of lexical structure}

The extension of lexical structure at the albanian language, is not the development of univocal words, but the whole language. The new meanings give the words a new structure. the univocal word has passed at ambiguous or polisemantic units. In other words, the language has activated an other well-balanced instrument of the linguistic system, so the development of polisemy. There are examined the increase of lexical content during these 30 years, but their numbers aren't equal with the value of eliminated meanings. So, if we put on the scales, the polisemantic words are a little. The question is raised: what is happening with albanian language?

Multimeanings or the phenomenon that they represent, the polisemy, has reduced its values at albanian language. The grouth of univocal words or the phenomenon that they represent, monosemantism, is finding new spaces at the language. The causes can be different. The most important thing is that language changes from many factors, which led these movement to present in the form and in the content way. The time is unavoidable. As long as it changes many manifestations, even the language can't save from it. So, we are going to uphold the sossyrian idea, which consist at " the language isn't free for so far that is under the factors which croos out the liberty", (Sossyr de F. 1972).

The language is a very clever human. It knows how to put the balances and respects the limits. It is true that we see a grouth of univocal units, but on the other hand, we have not to forget that language belives its functions the development of the meanings more than word-formation. Eventhough the word-formation has been very productive at our language, (Kostallari. A. 1972). If we take into account the join of many words at one lexical voice, we will see that the number of new lexical voice is about 1.5 times lower than the units which are created from the meanings. If we examine the content structure of the each units inside lexical voice, we will see that a great part of them are univocal words, because they are loaned. For example: stress, to stress, be stressed, stressed, to appropriate, be appropriated, ownership, appropriated etc. These kind of units will take a long time to generate new shades of meanings or figurative meanings.

The word in different contests could be develop more. The uses of words at different speeches and styles is an absolute necessity for the life of lexical units. In this way, every semantic version, eliminated or not, has a big importance, because they show the manner of content derivation. The semantic versions of the words don't born immediately. Because of that the units given up, are only at beginning period, so at the birth

\footnotetext{
3 Notes: The given examples are referenced the presantion of the words at "The Albanian nowdays language dictionary" 2006.
} 
period. These words will have a semantic development later, during the uses at different contests or after the formation of new words.

The lexical changes of the words let as a point of discussion, for the kind of semantic versions that the words benefit or lost. If we examine the semantic versions by the concret or abstract report, we will see that the greatest part of them belong abstract report ( about 140 examples). These numbers are for two albanian dictionaries. The meanings of abstract level show the removal of marker from the reality, meanwhile the meanings of concret level shows the approach between them. If we take as example the word-garnishingwe will find the new abstract meaning:-garnishing- 3. something unessential that serves to decorate something else; -to button- 2. to get a work properly settled; -well- 2. a person who is very secretive; -stuffcontent, quality content (for the peoples); -fire- disagreement, divergence etc.

As the result that these new meaning units belong abstract level, means that these meaning has noted the first removal step of marker from the reality, so the relation with the first meaning is weaker. These meaning will be candidates later to separated from the word structure, to lose the connections with other words, to put relation with new words, or to prepared as new lexical units. The derivation meanings to abstract level, give possibility the word to be as the naming of different realities. The supplement group of semantic versions push the polisemantic words towords losing of semantic versions. So, at this way can be more space for the development of univocal words.

\section{Conclusion}

As conclusion we can say that, it doesn't matter the quantitative of meanings that moves as numbering. The importance is the fact that albanian language during these 30 years is showing a light run of univocal words increase. The words have presented a moved content meaning, doing possible to change their statute from polisemantic words at univocal words and reversibly. This fact verify and the great number of univocal words, which are turned over at univocal words (about 570 lexical units). The content structure of the words is grown with 200 semantic versions, but this value is lower than the number of semantic versions which has came out from the dictionary.

On the other hand the increase of semantic versions which belongs the abstract level (they are about 140 semantic units), are an index not only for the increase of univocal words, but for the fortune of that lexical units, which belongs the same level. Their destination is the way to monosemantism. At this moment the problem is for all linguists, to find new ways how the language could equilibrate its system without problems for each part of system.

The number of eliminated meanings is higher than than the supplement meanings. They achive at about 1000 lexical meanings. The most important thing is that a great parts of these semantic versions are associated with stylistic note -figurativ-. That thing influences at the content structure of the words, because these kind of semantic versions have the possibility to generate new meanings, to derivy new meanings, eventhough to come out as new lexical units. So, this topic makes known that the polisemantic words are reducing, eventhough at little values. It is not the same thing for univocal words, which are increasing because of this phenomenon.

The language is alive, lives and always will present different changes. The linguistic development connect the whole linguistic system, but the lexic can feel it first of all. For that reason the lexic and lexicology will be forever an object of unresolved discussion. This study is an effort to give a little contribution at the improvement of datas at lexicology's and semantic's field.

\section{References:}

Kostallari, A. (1972/3). " Gjuha letrare kombëtare shqipe dhe epoka jonë" ("National literary language") at, "Studime mbi leksikun dhe mbi formimin e fjalëve në gjuhën shqipe" "The studies over lexic and word-formating at Albanian language"). 
Kostallari, A. (1972/3). "Mbi disa drejtime të përsosjes së sistemit e të strukturës së gjuhës sonë letrare" (" Over some of directions for the perfection of the structure at literary language") at "Studime mbi leksikun e formimin e fjalëve" ("The studies over lexic and word-formating at Albanian language").

Xhuvani, A. (1958). "Për pastërtinë e gjuhës shqipe" ("For the purity of albanian language"), p,70.

Xhuvani, A. (1956) "Studime gjuhësore" ("Linguistic studies").

Sossyr, de F. (1972). "Course in general linguistic", p, 89-101.

LEKA, F. (1972/2) "Aspekte të zhvillimit të terminologjisë tekniko-shkencore pas Çlirimit" ("Some aspects of the development of terminology after national liberation"), at "Studime mbi leksikun e formimin e fjalëve" ("The studies over lexic and word-formating at albanian language").

LEKA, F \& MORCKA, S. (1972/2). "Zhvillimi dhe pasurimi i terminologjisë pas Çlirimit" ("The development and enrichment of terminology after national liberation"), at "Studime mbi leksikun e formimin e fjalëve" ("The studies over lexic and word-formating at albanian language"), p, 185-194.

NDOCAJ, E.F. (1972/2). "Mbi fondin e fjalëve dhe kuptimet e tyre në "Fjalorin e gjuhës shqipe" (The lexical fond and their meanings at 'The albanian language dictionary'), at "Studime mbi leksikun e formimin e fjalëve" ("The studies over lexic and word-formating at albanian language").

"Fjalor i gjuhës së sotme shqipe" 1980 ("The Albanian nowdays language dictionary").

"Fjalor i gjuhës shqipe" 2006. ("The Albanian language dictionary").

Thomai, J (1984). "Leksikologjia e gjuhës shqipe" ("The lexicology of albanian language".

Thomai, J. (2006). "Prejardhja kuptimore në gjuhën shqipe" ("The lexical semantic at albanian language"), p,77. 304.

Thomai, J. (1972/1). "Mbi mënyrën e pasqyrimit të sistemit të kuptimit dhe të përdorimeve të fjalëve në fjalorin shpjegues të gjuhës shqipe" ("The system of meanings and the uses of the words at explanatory albanian dictionary") at "Studime mbi leksikun e formimin e fjalëve" ("The studies over lexic and word-formating at albanian language").

Lyons, J. (1968) "Introduction to therotical linguistc".

Haxhillazi, P. (1972/3). "Rreth karakteristikave stilistike të fjalëve në fjalorin e 1980" ("The stylistic features of the words at albanian dictionary of 1980") "Studime mbi leksikun e formimin e fjalëve" ("The studies over lexic and wordformating at albanian language”, p. 561-570.

Rrokaj, Sh. (2005). "Hyrje në gjuhësinë e përgjithshme" ("Introduction to general linguistic").

Lloshi, Xh. (1972/2). "Vëzhgime mbi homonimet në gjuhën shqipe" (" Observations over homonymys at albanian language") at "Studime mbi leksikun e formimin e fjalëve" ("The studies over lexic and word-formating at albanian language").

Lloshi, Xh. (1972/2). "Mbi rezultatet kryesore në studimin e leksikut dhe të formimit të fjalëve në gjuhën shqipe pas Çlirimit" ("The main results at lexic's study and the formatting of the words at Albanian language after the national liberation") at "Studime mbi leksikun e formimin e fjalëve" ("The studies over lexic and word-formating at albanian language").

Lloshi, Xh. (2005). "Stilistika dhe pragmatika" ("Stilistic and pragmatic"). 